Оригинални научни рад

808.5:343.1(37)

doi: $10.5937 /$ zrpfns $48-5427$

Tamás Nótári, Ph.D., Associate Professor

Károli Gáspár University Budapest

Faculty of Law

\title{
LAW AND RHETORICS IN CICERO SPEECH IN DEFENCE OF CNAEUS PLANCIUS
}

Abstract: The speech in defence of Cnaeus Plancius was delivered in early autumn 54 B.C. Cn. Plancius won the office of aedilis of the year 54 by winning the election, and, as it was not rare in Rome, his competitor, who lost in the election, M. Iuventius Laterensis charged him of election bribery/fraud (ambitus). Defence was provided by Cicero, who-as was his custom-rose to speak as the last one. The close relation between Cicero and his defendant was highly influenced by the fact that Plancius, who acted in Macedonia as proquaestor, gave shelter to the exiled politician, which was equal to saving his life in the orator's interpretation. Cicero responds to the allegations of general significance made by the prosecution, in not too exhaustive details, however, he turns the attention from the accused and his acts to his own person. After brief description of the historical background of the lawsuit, we analyse Pro Plancio more profoundly to investigate the rhetorical handling of the facts of the case, which will be compared to Pro Murena examined earlier at several points to ensure better understanding.

Key words: Roman criminal law; elections; crimen ambitus; bribery; Marcus Tullius Cicero.

The speech in defence of Cnaeus Plancius was delivered in early autumn 54 B.C., immediately before or after the oratio in defence of M. Aemilius Scaurus. Cn. Plancius won the office of aedilis of the year 54 by winning the election, and, as it was not rare in Rome, his competitor, who lost in the election, M. Iuventius Laterensis charged him of election bribery/fraud (ambitus). As co-prosecutor L. Cassius Longinus took sides with him, defence was provided by Cicero (and as quite often Hortensius), who- as was his custom-rose to speak as the last one. The court of justice was chaired by C. Alfius Flavus, of whom-in spite of his people's party affiliation - Cicero made positive statements elsew- 
here. The close relation between Cicero and his defendant was highly influenced by the fact that Plancius, who acted in Macedonia as proquaestor, gave shelter to the exiled politician, which was equal to saving his life in the orator's interpretation. Cicero responds to the allegations of general significance made by the prosecution, in not too exhaustive details; however, he turns the attention from the accused and his acts to his own person, and the style of the speech here is elevated to hymn of gratitude addressed to his friend and saviour, Plancius, who stood by the orator-statesman from first to last even during his exilium. As on several occasions earlier and later, he convincingly hammered the conviction into his audience that his voluntary and self-sacrificing exile saved the people of Rome from terrible civil war and bloodshed, and he tried to clarify his relation with the triumvirs far from being free from contradictions, yet stylised into a harmonic relation in the given situation. By describing his exile and escape in vivid colours and presenting a stylised figure of Plancius as a heroic saviour, he aroused the audience's compassion with the accused in a pathetic peroratioand not without impact since, as it is known, in the proceedings Plancius was acquitted.

After brief description of the historical background of the lawsuit (I.), we analyse Pro Plancio more profoundly to investigate the rhetorical handling of the facts of the case, which will be compared to Pro Murena examined earlier at several points to ensure better understanding. (II.) Although the case was not one of the events that stirred huge political storms in the last century of the Republic, and so it was soon forgotten, it can be considered important among charges brought due to election bribery and lawsuits conducted on this subject to the extent that, after Pro Murena, Pro Plancio is the second - and the last - speech delivered by Cicero in ambitus lawsuits that have been left to us, which provides us with the opportunity for profound and comparative analysis of the Ciceronian handing of the facts of the case that he usually applied in crimen ambitus.

\section{The historical background of Pro Plancio}

Cnaeus Plancius came from a family in the order of knights (ordo equester); he was born presumably in 96 as the son of an honourable and wealthy publicanus. After he acted as tribunus militum and quaestor, he applied for aedilis's office in 55, running together with Iuventius Laterensis, somewhat younger than him, as his opponent. At that time, he won the majority of the votes cast; however, the election was postponed, and was repeated in the following year. ${ }^{1}$ Plancius and A. Plotius won, Laterensis and Q. Pedius - the latter obtained very few votes-lost the election. ${ }^{2}$ Laterensis did what many people did in

\footnotetext{
${ }^{1}$ Cic. Planc. 50.

${ }^{2}$ Cic. Planc. 17.
} 
such a case in Rome: he brought a charge of ambitus, i.e., election fraud/bribery against Plancius. Beside Laterensis, L. Cassius Longinus, brother of one of Caesar's later assassins, acted as co- or secondary accuser; the defence was provided by Hortensius and Cicero. As the basis of the charge he did not choose lex Tullia de ambitu created in 63 during the period of Cicero's consulship but lex Licinia de sodaliciis created in 55 on Crassus's initiative to sanction use of associations set up for distributing bribes during election campaigns. This law seemed to be more favourable to the prosecutor not because of its sanction-since earlier laws held out the prospect of properly strict punishment: ten year exile, expulsion from the senate, being barred from applying for offices for life and a certain fine - but because of its procedural law aspect. For, in accordance with this law, the prosecutor could determine the four tribus from whom the judges had to be selected and the accused could refuse only one tribus, that is, his right of reiectio - right to to expel certain judges without any special reason-was considerably impaired compared to usual quaestio proceedings. In the procedure, actually used in practice, first the accused had to name the judges whom he was related to by marriage and kinship or confidential relation as a member of the same sodalicium or collegium, in twenty days. Then, the prosecutor selected one hundred from among the four hundred and fifty judges (editio), who were not allowed to maintain the above-mentioned relations with the prosecutor; after that, as part of his right of reiectio, the accused was allowed to reject fifty from among the designated one hundred judges, within forty days. ${ }^{3}$

Since it evolved in relation to winning the office of aedilis and not consul, the lawsuit did not have great political significance; however, Cicero had to cope with a rather critical situation due to his personal relations with the accused and the accuser ${ }^{4}$ because both Plancius and Laterensis and his family did significant services and favours to him during his exile. ${ }^{5}$ As he was more indebted to Plancius, whom he had supported during his election campaign already, due to the outstanding officium to him he had to undertake his defence. ${ }^{6}$ Laterensis obviously took it in bad part, ${ }^{7}$ and tried to lessen Plancius's services done to and merits obtained regarding Cicero. ${ }^{8}$ It was not by chance that Cicero noted at the beginning of his speech that he hoped that in passing judgment the judges would appreciate the merits that Plancius obtained with regard to the one-time consul, all the more because the court of justice consisted of mostly Cicero's

${ }^{3}$ Kunkel 1974b 69. About the role of collegia in the election campaign see Kornemann 1900. 380; Laser 1997. 102.

${ }^{4}$ Cf. Cic. Planc. 79.

${ }^{5}$ Cf. Cic. Planc. 73.78.

${ }^{6}$ Kroll 1937. 128.

${ }^{7}$ Cic. Planc. 72.

${ }^{8}$ Cic. Planc. 4. 95. 
friends and good acquaintances, which gave hopes for the acquittal of the accused from the first; ${ }^{9}$ it was just their emotions that the orator wanted to move in his ${ }^{10}$ peroratio formulated with huge pathos as usual.

\section{Cicero's rhetorical skills in Pro Plancio}

To the best of our knowledge, Cicero acted as counsel for the defence at least on eight occasions in criminal actions due to election fraud/bribery (ambitus), however, not all the speeches were published and only two of them have been left to us: the oratio delivered in 63 in defence of Lucius Licinius Murena elected consul and Cnaeus Plancius elected aedilis in 54. It is striking in both lawsuits that Cicero deals with the state of facts of ambitus and tries to refute the allegations made by the prosecution in merely one-fourth ${ }^{11}$ and one-fifth ${ }^{12}$ or, in the latter case, stricto sensu, one-twentieth ${ }^{13}$ - of the oratio. This similarity allows to infer that what we have here is a rhetorical tactics independent of the specific case, which the judges and the audience actually expected the advocatus to come up with in ambitus lawsuits. ${ }^{14}$ It might also arouse the attention that in both speeches Cicero speaks about himself at length, which is not justified by the legal facts of the case at all. The explanation for this is found in the practice of Roman orators as in Rome it was not only his rhetorical competence but his entire authority that an advocatus or a patronus made available to the accused or cliens brought before court and thereby guaranteed the authenticity of the case undertaken and the person defended, by full weight of his personality to the judges - what is more, he identified himself with his acts and fate. ${ }^{15}$ Accordingly, the opponent, as a matter of fact, worked towards attacking and shaking the authenticity of both the accused and his defending counsel; therefore, in the two particular cases the prosecution considered it necessary to speak exhaustively about Cicero too. This custom can bee seen again, for example, in Pro Cluentio $^{16}$ and is explained in De oratore. ${ }^{17}$

In Pro Murena, the orator feels it necessary in the prooemium already to respond to reproaches against him for having undertaken the case at all. ${ }^{18}$ As one of the four accusers, beside Servius Sulpicius Rufus, who lost the elections,

\footnotetext{
${ }^{9}$ Cic. Planc. 2. 4.

${ }^{10}$ On the peroratio see Cic. Or. 128. sqq.

${ }^{11}$ Cic. Mur. $54-77$.

${ }^{12}$ Cic. Planc. $36-57$.

${ }^{13}$ Cic. Planc. 53b-57.

${ }^{14}$ Adamietz 1986. 102. sq.

${ }^{15}$ Thierfelder 1965. 385. sqq.

${ }^{16}$ Cic. Cluent. 140. sq.

${ }^{17}$ Cic. De orat. 2, 220. sqq.

${ }^{18}$ Cic. Mur. 2b-10.
} 
and S. Sulpicius Rufus junior and C. Postumius, not known specifically, M. Porcius Cato-who took an oath in public before the elections that if the election would be won by any other person than his brother-in-law, Silanus, he would bring a charge of ambitus against him ${ }^{19}$ — criticised Cicero (although as a consul he created lex Tullia de ambitu ${ }^{20}$ which held out the prospect of ten year exile as a new punishment and took firmer action against those who distributed money) for having undertaken the defence of Murena charged of election bribery. Cicero was highly criticised also by Servius Sulpicius Rufus, the most significant jurist of the age, who considered Murena's defence a betrayal of their friendship. All this was meant to undermine the authenticity of Cicero as a defending counsel, which would have weakened his defendant's position too. ${ }^{21}$

In Pro Plancio, Cicero notes that in their statement for the prosecution M. Iuventius Laterensis and L. Cassius Longinus spoke more about him than about Plancius; ${ }^{22}$ accordingly, in the third third of his oratio Cicero discusses solely his own person and the services and favours done to him by Plancius. ${ }^{23}$ Several allegations of the prosecutors were involved in the statement of the defence in the form of remarks; for example, the allegation that in the description of his own exile Cicero went too far in praising Plancius's merits. ${ }^{24}$ The merits obtained by the accused with regard to the defending counsel are described in details not only in Pro Plancio; ${ }^{25}$ Pro Sestio also contains longer arguments with such content. $^{26}$ Obviously, the prosecutors' intention must have been to separate Plancius completely from the judges' sympathy towards Cicero owing to his exile, that is why Laterensis insisted on his allegation that the merits Plancius had obtained regarding Cicero's exile - if they were true at all — should not have any weight in the judges' eyes. ${ }^{27}$ In harmony with that, the prosecutors recalled scornfully that Cicero had begged in tears to the judges in vain in defence of Cispius, who also did several services to him. ${ }^{28}$

The rather trivial commonplaces brought up as argument by Laterensis included the point that Cicero had earlier as a consul caused to involve exile in the sanctions ordered by lex Tullia de ambitu for no other reason than to be able to make the peroratio of his defence speeches more efficient. ${ }^{29}$ Also, he reproac-

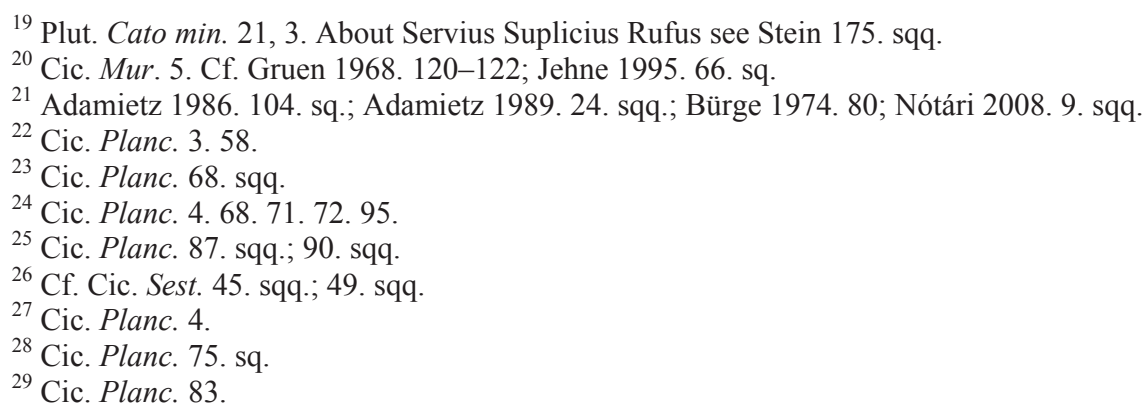


hes the orator for his years of study on Rhodos in order to point out that the moral looseness of eastern provinces must have been dear to Cicero. ${ }^{30}$ It is rather double-edged criticism by the prosecutor that Cicero failed to exploit the point inherent in Laterensis's stay on Crete: the play on the words island and chalk (creta). ${ }^{31}$ For applicants for offices made their clothes more shining and white by chalk, which was prohibited by law very early, in $432 .{ }^{32}$ Furthermore, he condemns Cicero for addressing a letter on his consulatus to Pompeius, the commander, probably with unpleasant content, highly stressing his own merits, which circulated in Rome-we have no further information on its content as it has not been left to us. ${ }^{33}$ Similarly, he criticises Cicero's decision that he had gone into exile instead of undertaking fight - attributing all this to Cicero's cowardice ${ }^{34} \mathrm{He}$ does not omit to emphasise that Cicero is not acting by free will at the time when the speech is delivered either-suggesting dependence on Pompeius. ${ }^{35}$ All this, although has nothing to do with the facts of the case, served to undermine the authority of the defending counsel and thereby the authority of his defendant. ${ }^{36}$

The personal motivation of the prosecution is clear since in Rome a prosecutor did not have to be objective and unbiased at all. ${ }^{37}$ In the charge of ambitus the accusers who had lost the elections might have been driven by the motive that if the accused elected for the given office were convicted, they could take their place ${ }^{38}$ as it did happen in 65 in the case of L. Aurelius Cotta and T. Manilius Torquatus after P. Cornelius Sulla and P. Autronius Paetus elected consul had been convicted. There were good chances for Servius Suplicius Rufus and Marcus Iuventius Laterensis hoping for the same in the event that Murena and Plancius were convicted. Anyone who decided to bring a charge, as a matter of fact, exposed himself to personal attack by the defending counsel. ${ }^{39}$ It was not by chance that Torquatus referred to Cicero's tyranny and autocracy (regnum) in court of justice in the lawsuit against Sulla ${ }^{40}$ as Cicero was not sparing with attacks against the prosecutor, tribune L. Labienus in Pro Rabirio perduellionis. ${ }^{41}$

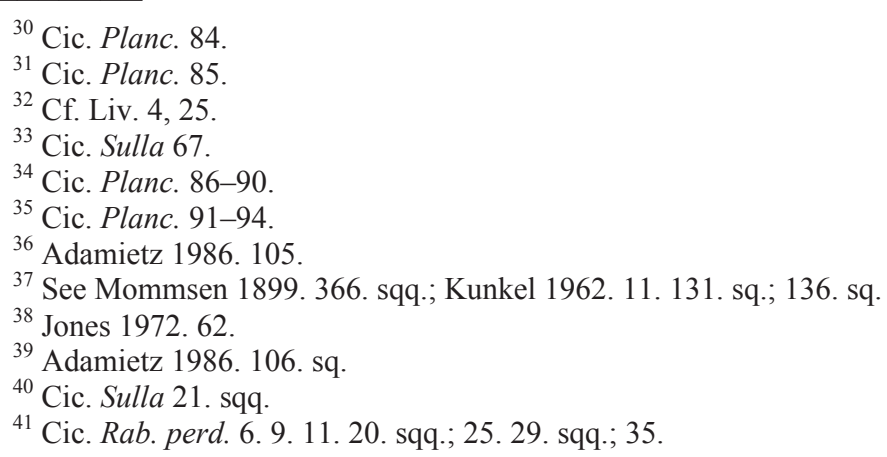


The attacks against Cicero were of great weight in the Plancius lawsuit and in several cases hit Cicero in sensitive points: Cassius brought up Cicero's attempt at entering into alliance with Pompeius, which, however, failed, ${ }^{42}$ Iuventius reproached Cicero for undertaking Cispius's defence, and in connection with that he parodied the famous "quo usquem" passage ${ }^{43}$ of the first Catilinaria $;^{44}$ similarly, they ridiculed his pathetic perorationes. ${ }^{45}$ All this, however, was dwarfed by their suspecting him of leaving Rome in 58 and going into exile out of cowardice and sacrificing his freedom to flatter the triumviri-the orator responded to it in natural and deep indignation. ${ }^{46}$ Briefly but resolutely, he attacked his enemies at the time, Clodius, Gabinius and Piso. ${ }^{47}$

Furthermore, in both lawsuits against Murena and Plancius, Cicero had to cope with the difficulty that the adverse parties in the lawsuit, that is, the prosecutors, were his good friends. He supported Sulpicius in his election struggles, and maintained relations with Labienus's family since his exile, however, Murena's acquittal was definitely in the interest of the State because that was the only way to ensure that at the beginning of the year two dynamic consules could take over control over the state organisation undermined by the conspiracy, and it is an undeniable fact that Plancius did much greater service to Cicero by providing him with shelter in Thessaloniki than Labienus's family. Therefore, the orator could not use the well-tried strategy of stressing his defendant's merits by dealing the opponent a devastating blow; instead, he had to find some middle-ofthe-road solution by which he could both clear the accused and was not compelled to start a serious attack against the prosecutor. ${ }^{48}$ It was not by chance that Quintilian noted that in Pro Murena Cicero acknowledged Sulpicius's all virtues and although he praised him, he advised him not to apply for consulatus. ${ }^{49}$

The fundamentum ac robur totius accusationis, ${ }^{50}$ that is, the attack against Cato was justified just by the unquestionableness of his motifs and singular authority. It was just this authority that made the senators at the session of the senate held a few days after Pro Murena was delivered, on $5^{\text {th }}$ December 63, in the Concordia Temple ${ }^{51}$ join what Cicero summed up in the fourth Catilinaria, in opposition to Caesar, who proposed life imprisonment of the conspirators, ${ }^{52}$ af-

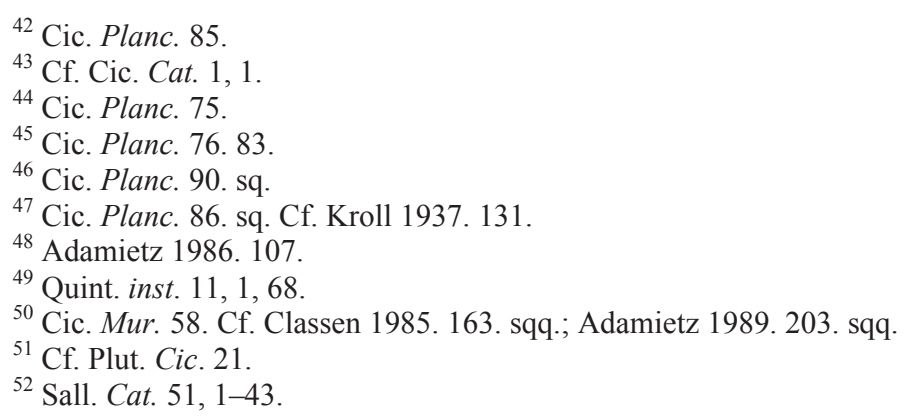


ter Cato had also demanded death penalty for the traitors, ${ }^{53}$ which was executed that evening in Tullianum. It was just this that Cicero tries to defend against in his ironic attack against Cato's cold stoicism so that the statesman's unbelievable authority, that is, purely his name should not be detrimental to the accused. ${ }^{54}$ Acknowledging Cato's moral greatness, he endeavours to present his standpoint taken in the particular matter as a trait alien to life, alien to the spirit of Roman people in order to take the edge of the charge and ruin the image in the judges that anyone Cato has resolved to bring a charge against must be by all means guilty. ${ }^{55}$ It is not by chance that the edited version of Pro Murena left to us does not contain detailed refutation of the charges made by Servius Sulpicius junior and Postumus - as the arguments brought up by them were not backed by moral authority similar to that of Cato, Cicero was not compelled to take the sting out of their argument by delicate shading. ${ }^{56}$

In legal terms, it does not belong to the charge and its refutation either to compare the life and activity of the competitors, having lost in the election struggle, acting as accusers in the ambitus lawsuit, to that of the winners of the election, the accused parties of the lawsuit. Cicero, however, in response to the allegations of the prosecution, touches on the conduct of life of the accused parties (reprehensio vitae), ${ }^{57}$ the comparison of the eligibility, authority and worthiness of the office of the accused parties having won and the accusers having lost in the elections (contentio dignitatis). ${ }^{58}$ Only after that does he deal with the crime of election bribery/fraud rather briefly and try to refute the relevant charges (crimina ambitus) - in the case of Pro Murena, also by inserting, before the fact-based, yet rather taciturn and not really convincing refutation, ${ }^{59}$ the response to the motifs of the charges brought up by Cato. ${ }^{60}$

The examination of the conduct of life of the accused parties (vita anteacta) is of a highly critical tone in the statement of the prosecution in both cases. Cato reproached Murena for his stay in Asia and the presumption that he took pleasure in eastern luxury, ${ }^{61}$ his sympathy for dancing, which was not worthy of a free Roman citizen in the eyes of the Romans ${ }^{62}$ - however, none of these criticisms was connected with the crime of ambitus. The prosecutors reproached

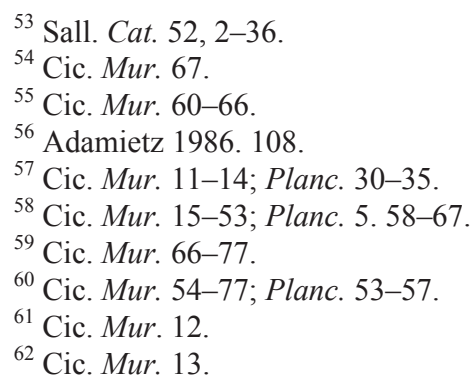


Plancius for the charge of bigamy, ravishing an actress, Atinia, ${ }^{63}$ releasing a prisoner from prison unlawfully ${ }^{64}$ and the too resolute action taken by his father, Plancius senior for the sake of publicani. ${ }^{65}$ These allegations were not connected either directly or indirectly with the actual charge, ambitus. However, accumulation of charges not supported by facts - more exactly, as Cicero often stressed it: abusive language and defamation-was general practice in any lawsuit, not just ambitus lawsuits, as a tool of influencing the climate of opinion against the accused. ${ }^{66}$

In ambitus lawsuits it was traditional to compare the competitors' dignity, eligibility for office (contentio dignitatis) both by the prosecution and the defence. In Pro Murena this constitutes a rather lengthy, independent part; ${ }^{67}$ in Pro Plancio-referring to the sensitivity of just the accuser, Laterensis ${ }^{68}$ - Cicero rejects the use of this tool; ${ }^{69}$ later on, however, albeit, emphatically in response to Crassus's counts of the indictment, he uses them anyway. ${ }^{70}$ By all that, the defending counsel tries to achieve a double result: on the one hand, he wants to prove his defendant's high eligibility for the office to be filled; on the other hand, he explains the causes of his election victory. Simultaneously, he gives explanation for the accuser's election defeat, arguing that it was due to the defeated party's fault and not to his defendant's acts, even less to possible bribe. ${ }^{71}$ Accordingly, in the part of Pro Murena that can be called contentio dignitatis, discussion of Sulpicius's defeat was given an important place too, ${ }^{72}$ and in Pro Plancio it is after the seeming rejection of the opportunity of contentio ${ }^{73}$ that the orator comes to Laterensis's election defeat on two occasions. ${ }^{74}$ The structure of contentio is identical in both speeches: Cicero discusses the career of the competitors in chronological order. ${ }^{75}$

In Pro Murena, in response to Sulpicius's argument that he outdoes Murena in social background, the orator underlines the significance of individual achievements, ${ }^{76}$ and to the fact that he was announced first in the election of the

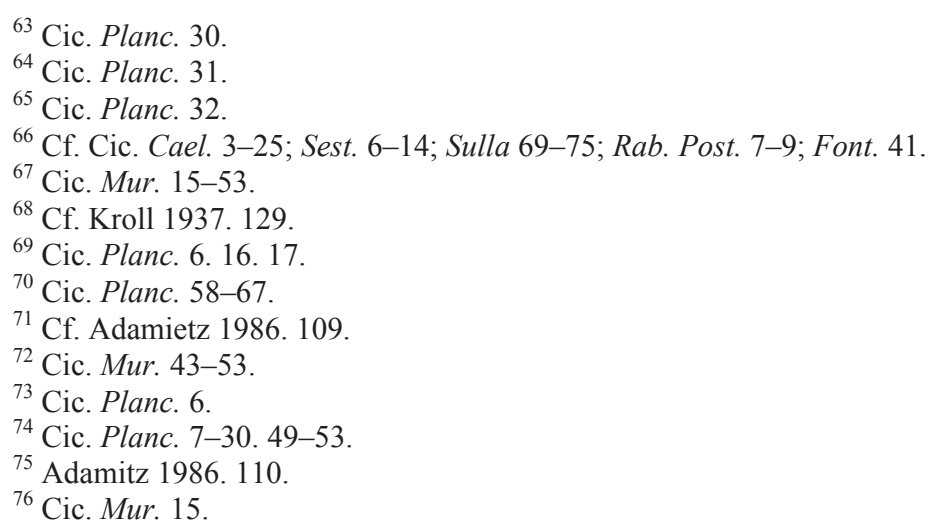


quaestor he opposes the point that what must and can be investigated on the merits is nothing else than the achievements attained in office filled in the same year-and in this respect none of them excelled. ${ }^{77}$ In response to Suplicius's argument that he would have been more worthy of consul's office because he stayed in Rome from first to last, while Murena stayed in the east as commander, Cicero points out that it is not presence but merits that count. ${ }^{78}$ At this point, in studiorum atque artium contentio, the orator opposes soldier's activity to lawyer's activity and involves the art of rhetoric as a third element in the comparison, and this way jurisprudence as a profession dealing with unnecessarily overcomplicated, insignificant matters is given the third place only. ${ }^{79}$ Praise of res militaris is a response to Cato's criticism that Murena's merits as commander are insignificant, if for no other reason, because the war in Asia was fought against women and not men. ${ }^{80}$ Cicero beats off the argument of victory obtained in the first place in the election of praetores by the topos of the unpredictableness of public opinion, ${ }^{81}$ and underlines the magnificence of the games arranged by Murena, and opposes it to the fact that Sulpicius had not arranged any. ${ }^{82}$

Furthermore, Cicero emphasises that the electors appreciated Murena's role fulfilled in administration of justice, contrary to the severity engaged by Sulpicius in this respect, which arose from the nature of the field he controlled, and that the commander's activity in the provinces also provided him with great support, whereas the jurist was not willing to assume any task outside Rome. ${ }^{83}$ After discussing the causes of Murena's victory, he comes to the direct causes of Sulpicius's defeat. Electors clearly noticed that Sulpicius did not strive for winning the elections in the first place, instead, he dealt with the opportunity of bringing a charge in case he would lose and collecting evidence against his rivals, which suggested that he did not see many chances for victory. ${ }^{84}$ Furthermore, he fought for making lex Calpurnia, which sanctioned ambitus, stricter, and in this effort he was supported by Cicero as consul and friend by creating lex Tullia de ambitu-yet, this had not made him sympathetic to electors either. ${ }^{85}$ Finally, the critical political situation, i.e., general fear of Catilina's possible victory, favoured Murena, whom citizens considered a firm support against threatening danger, while they did not

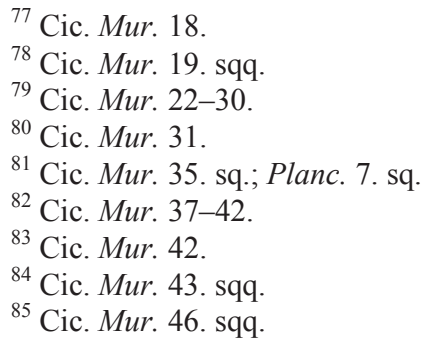


presume that the anxious and hesitating Sulpicius would take such a firm action. ${ }^{86}$ To sum it up: Cicero took the position that Murena's victory arose from his own excellence and the faults made by his rival, Sulpicius but by no means from unlawful practices and bribery. ${ }^{87}$

In the Plancius lawsuit Cassius criticised and condemned Cicero's defendant, ${ }^{88}$ while he appreciated Laterensis's merits and competencies. ${ }^{89}$ Whereas the opponent underlined Laterensis's nobilitas and deemed him worthy of the aedilis's office owing to his social background, Cicero (just as Plancius in Murena's lawsuit) emphasised individual virtus, merits, aptitude in the case of homo novus. ${ }^{90}$ A homo novus, in other words, a person whose ancestors did not get higher offices (cursus honorum), was in certain respects in a disadvantageous position in the struggle for winning given offices compared to the members of the nobilitas because the latter could proudly refer to their ancestors' deeds carried out for the benefit and greatness of the people of Rome. The homines novi who achieved the highest degree of public dignity, in several cases - as it can be observed in the example of Cato maior or Cicero - followed ancient ideals more consistently and, one should say, with neophyte enthusiasm. Prior to Cicero, it was in 94 when a homo novus, more specifically, C. Coelius Caldus, was elected consul. At the same time, Cicero-in order to win the people's support and make advantage out of disadvantage- voiced the rather populist view that members of the nobility handled the consul's office as their own privilege, and proudly emphasised his own merits, by which he was able to get the highest dignity of the State (res publica) even against the nobility. ${ }^{91}$

Anyway, regarding Laterensis he used the tools of humanitas and urbanitas as the accuser did not belong to his personal enemies. ${ }^{92}$ In the case of Plancius, Cassius challenged lack of triumphi, military achievements, rhetorical and jurist competencies - that is, there are good chances that he used the arguments that Cicero formulated in Pro Murena with regard to various professions. In response, Cicero as defending counsel expounded that the opportunity of triumphus would become available, for that matter, through holding given offices, and that by his activity on Crete and in Macedonia he did prove his military aptitude, and that he had never claimed to have knowledge obtained in rhetoric and jurisprudence, instead, he could show prominence in character, which was much

\footnotetext{
${ }^{86}$ Cic. Mur. 48. sqq.

${ }^{87}$ Adamietz 1986. 110. sq.

${ }^{88}$ Cf. Cic. Planc. 58. sqq.

${ }^{89}$ Cf. Cic. Planc. 63.

${ }^{90}$ Cic. Planc. 59. sq.

${ }^{91}$ Cic. leg. agr. 2, 3

92 Kroll 1937, 129.
} 
more appreciated by the people of Rome than professional knowledge..$^{93}$ At the same time, Cicero lessens the weight of Laterensis's merits obtained in Cyrene also to his detriment by an ironical dialogue narrated in relation to his activity as proquaestor in Sicily, with the morals that Laterensis would believe in vain that he had carried out significant deeds in remote provinces, the public might have not even heard of his being away from Rome. ${ }^{94}$

To take care of the sensitivity of the opponent who otherwise maintained good relations with him, Cicero discusses the reasons for Laterensis's election defeat separately from contentio dignitatis, ${ }^{95}$ and gets down with it primarily by the topos of the unpredictableness of public opinion and unreliability of public judgment. ${ }^{96}$ The tricks of winning mercy of the people were discussed in details by his brother, Quintus Tullius Cicero in Commentariolum petitionis where he expounded that applicants should formulate what they have got to say in accordance with electors' desires and needs rather than their own conviction, and pointed out that promises made kindly are more important than keeping such promises. ${ }^{97}$ Apparently, it was just this that Plancius forgot about, and before the court of justice consisting of senators and knights Cicero could safely refer to the shaky and unreliable value judgment of the people, ${ }^{98}$ and, to completely reduce the edge of the attack against Laterensis, he declared that if the people had had firm conviction, had orientated themselves in terms of merits and values in forming their opinion, then they would have elected Laterensis aedilis. ${ }^{99}$

The people blamed Laterensis for not making efforts to win their favour and for relying on the advantages provided by his social background only in winning the election. ${ }^{100}$ Similarly, giving up the fight for tribune's office already commenced in 59 was to his detriment because the public considered it indifference, ${ }^{101}$ and asserting his high-born origin might have evoked antipathy instead of sympathy in the plebs. ${ }^{102}$ Later on, Cicero returns again to the thought that Laterensis's defeat was caused by lack of humbleness to be engaged to the mercy of the people (supplicare, se submittere) ${ }^{103}$ The consequences of Laterensis's faults were increased by the circumstances that supported Plancius: the

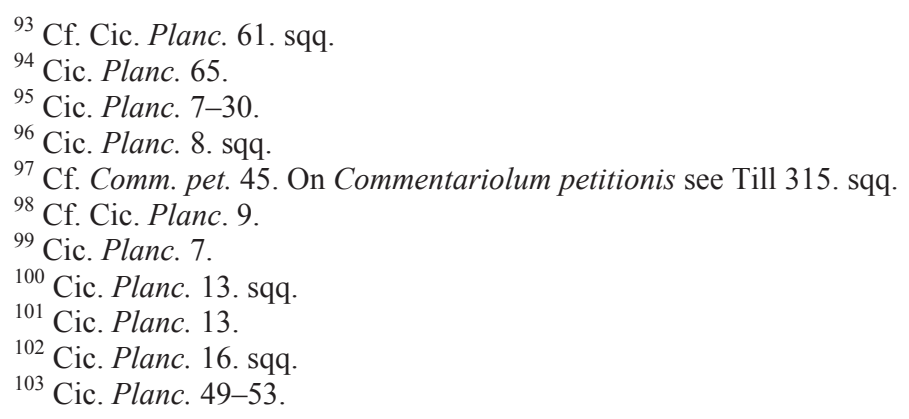


support of his home town, ${ }^{104}$ the commitment of publicans ranged on his side by his father, the leader of the publicani, ${ }^{105}$ and Cicero's help, who thereby thanked Plancius for the favours he had done to him during his exile. ${ }^{106}$ Furthermore, his activity in Africa, on Crete and in Macedonia, ${ }^{107}$ and his successful tribune's activity was in favour of Plancius. ${ }^{108}$

It should be noted with regard to publicani, that they made it possible that state administration with a low headcount had to be maintained in Rome because well-to-do publicani, most often from the order of equites, constituted a company for the economic implementation of important goals in the life of the State (for example, construction of water pipes, providing the army with arms). The late age of the Republic used the terms knights and publicans often as synonyms; however, overlapping between the two categories by no means meant identity: some publicans had assets between forty thousand and one hundred thousand sestertii, while the extent of knights' census was set as four hundred thousand sestertii. In the company of publicans the members assumed burdens and shared benefits in proportion to their share; the most propertied were accountable to the State for implementing the enterprise usually by their landed estate; on behalf of the State the magistratus entered into a contract with them. The key task of publicans was their role assumed in taxation in the provinces: they paid the amount of tax determined for the given province to the state treasury in advance, and on the leased territory during the lease period they could freely collect the amount they had paid in advance. The governors, as a matter of fact, often abused their position and imposed unlawful burdens on provinces; so, inhabitants were compelled to take out loans from publicans, who usually disbursed the amount demanded at usurious interest rates. Accordingly, judgement of publicans was disputed; in his letter to his brother - as a matter of fact, in a statement not addressed to the general public - Cicero himself called them the greatest burden of provincial administration. ${ }^{109}$ In several cases publicans supported the election of persons favourable to them by covering a major part of their campaign costs - it was not by chance that Cicero's brother, Quintus tried to convince him that he should win publicani's benevolence to support his own consul campaign. ${ }^{110}$ Cicero called publicans the flower of the order of knights of Rome, ${ }^{111}$ the knights themselves strong support of the rest of the orders. ${ }^{112}$

\footnotetext{
${ }^{104}$ Cic. Planc. 19. sqq.

${ }^{105}$ Cic. Planc. 23.

${ }^{106}$ Cic. Planc. 24. sqq.

${ }^{107}$ Cic. Planc. 27. sqq.

${ }^{108}$ Cic. Planc. 28. 61.

${ }^{109}$ Cic. Q. fr. 1, 1, 32.

${ }^{110}$ Comm. pet. 3.

${ }^{111}$ Cic. Planc. 23.
} 
C. Gracchus already relied on knights actually as an order, and entrusted Asia province to them as publicans.

In Pro Plancio a peculiar element of contentio dignitatis is the projection of the personality of the two candidates to their hometown, Tusculum in the case of Laterensis and Atina in the case of Plancius. Tusculum was a distinguished settlement south-east of Rome, where several consuls' families came from. Therefore, it is understandable that the inhabitants of Tusculum - as numerous men who had held consulship lived in the town - did not attribute special significance to Laterensis's aedilitas; consequently, they did not make many efforts to help him to win the desired office. Atina, lying not far from Cicero's hometown, Arpinum, was far from being so respectful and notable; so, its inhabitants made more efforts to help one of the citizens born at their settlement to win the aediliias since thus glory fell on them too, which the inhabitants of Tusculum had plenty of. ${ }^{113}$

Therefore, by contentio dignitatis Cicero tried to shed light primarily on the fact in both speeches - by analysing both the virtues and strengths of the winner/accused and the faults and failures of the loser/accuser- that his defendants had not been in need at all of trying to influence the outcome of the election by bribery as there were sufficient arguments that made them sure of their victory. Thereby he indirectly proved that the charge of ambitus was unfounded. Secondly, however, contentio dignitatis served to enable him to prove to the judges, as public opinion representing electors, that the winner of the election was by all means more suitable for the given office than his opponent - the enumeration of faults and failures committed during the election campaign was also meant to support the above as reasons for the train of thoughts that a person who controls his election campaign with more aptitude will hold the office more efficiently. Based on all that it can be inferred that the orator wanted to convince the judges also of the point that not only should the winner be acquitted for lack of crime but the results of the elections should not be invalidated due to the person's eligibility and the accuser's ineligibility either. ${ }^{114}$

Refutation of the charge of ambitus on the merits is very short, almost insufficiently concise in both speeches. ${ }^{115}$ The reason for that can be looked for, on the one hand, in the fact that from both lawsuits only Cicero's speeches have been left to us, so neither the statements of the prosecution, nor the rest of defence speeches are known to us, and as in both lawsuits Cicero rose to speak as the last one as was his custom, we could presume that the defending counsels

\footnotetext{
${ }^{112}$ Cic. Verr. 2, 2, 7.

${ }^{113}$ Cic. Planc. 19. sqq.

114 Adamietz 1986. 113.

${ }^{115}$ Kroll 1937. 132.
} 
taking the floor before him had already refuted the legally relevant counts of the indictment on the merits of the case, point by point. At the same time, it can be presumed that Cicero would have somehow referred or alluded to these refutations-however, no traces of that can be found. It is highly probable that both the prosecution and the defence set out from arguments related to person, and counts of the indictment that could be specifically supported and refuted did not play any considerable part - if for nothing else, due to the low number of proofs arising from the character of the cases. Defending counsels much rather tried to prove - all the more because the dividing line between ambitus sanctioned by law and morally contestable and legally acceptable ambitio could not be sharply drawn - that in the course of winning the electors' favours no scandalous, exaggerating steps contrary to traditions and customs were taken. ${ }^{116}$ Due to the indistinct dividing line between ambitus and ambitio we can possibly accept Kroll's statement that these Ciceronian speeches can be considered, for that matter, praise of properly and moderately exercised ambitus too. ${ }^{117}$

In Pro Murena Cicero argued that whereas Cato disapproved any kind of search for electors' favours, that is, entourage, hospitality and distribution of free tickets to circus and theatre performances, Murena, in the course of all these steps, took care of complying with and respecting generally accepted customs to sufficient extent: he recruited entourage not for money and theatre seats and feasts were made possible by his friends' generosity, which was not prohibited by law or unwritten law either. ${ }^{118}$ In Pro Plancio he could simply respond to the charge that Plancius entered into coitio, that is, alliance allowed by law with the other winning candidate, Plotius: originally it was Laterensis who wanted to enter into alliance with Plancius, however, it failed. At this point, it is possible to presume the cause behind the argument of the prosecution: it was not Laterensis that the agreement set out in the coitio favoured. ${ }^{119}$ The circumstances of distributing money in Circus Flaminius, the origin and function of the money could not be determined exactly and could not be proved, so this charge seemed to be weightless too ${ }^{120}$ - at least in Cicero's narrative. And for lack of proper evidence, Cicero could easily consider all the other statements gossip and defamation. ${ }^{121}$

Thus, based on all that, Plancius did not amount to the state of facts of lex Licinia, and demanding the application of this law was nothing else than a bad faith manoeuvre from the first by the prosecution to make the situation of the

\footnotetext{
116 Adamietz 1986. 114.

${ }^{117}$ Kroll 1937. 132.

${ }^{118}$ Cic. Mur. 68-77.

119 Kroll 1937. 133.

${ }^{120}$ Cic. Planc. 55.

${ }^{121}$ Cic. Planc. 53-57.
} 
accused more difficult. ${ }^{122}$ The provision of lex Licinia that set forth that the prosecution could designate four tribus, of which the judges were selected, was used by Laterensis contrary to the spirit of the law, ${ }^{123}$ since he left out just the Voltinia district where bribes had purportedly taken place, and whose judges for this reason could have judged the case with greater overview-Cicero's above opinion was obviously shared by Hortensius too, who expounded it in his own defence speech on the day before Cicero's oration was delivered. ${ }^{124}$ It was undoubtedly impossible to prove Plancius guilty of communis ambitus because this would have required to certify that distribution of money was carried out in an organised form, directly launched by the candidate - in other words, gratia and observantia of allowed extent only helped Plancius on the side of his friends and supporters. ${ }^{125}$

Basically, Pro Murena and Pro Plancio are made of identical elements, although the elements are arranged somewhat differently. Both the prosecution criticises the defending counsel, Cicero and Cicero resolutely criticises and attacks the accusers, Cato, Suplicius and Laterensis, not sparing sarcasm. On the one hand, the prosecution endeavours to make the person of the accused, having won the elections, inauthentic during reprehensio vitae, and thereby support the necessity of ambitus. On the other hand, the defence tries to prove ineligibility of the defeated accuser through contentio dignitatis to convince the judges thereby that the losing party can reproach nobody else than himself for his defeat, and for this reason the winner had not only not committed any fraud or bribery during the election campaign, but he was not in need of it either. It clearly explains this tactics when we consider that in case the winner was convicted, then the loser placed behind obtained the office that constituted the subject of the dispute; that is, if the counts of the indictment proved true, it guaranteed, in addition to conviction and punishment of the accused, that the accuser, having lost the elections, could win the office not obtained by votes. The fact-based refutation of crimina ambitus crowned this argument only but had no exclusive value for the outcome of the lawsuit, all the less as the judgment in the action-at-law unambiguously contained a political decision too. The jurors voted not only on guilt and innocence but on the fate of the office to be fulfilled; therefore, their vote was influenced, in addition to the case of ambitus, by their conviction developed of the eligibility of the accuser and the accused, that is, the parties opposed as competitors in the election struggle. ${ }^{126}$

${ }^{122}$ Kroll 1937. 134

${ }^{123}$ Cic. Planc. 42.

124 Cic. Planc. 37.

${ }^{125}$ Cic. Planc. 44. sq.

${ }^{126}$ Adamietz 1986. 115. 
In both cases the orator builds his statement by combining these elements in accordance with the circumstances. In the prooemium of Pro Murena he immediately responds to the objections of the prosecution that are aimed at Cicero undertaking the defending counsel's tasks as a consul in office and thereby betraying his friendship maintained with Sulpicius, ${ }^{127}$ and in the peroratio he uses the dignity of his office as a weapon that can be used for the sake of his defendant. ${ }^{128}$ Before addressing specific charges, he believes it is useful to convince the judges that Murena's conduct of life is irreproachable and he is eligible for the office, ${ }^{129}$ which he emphasises in a lengthy contentio dignitatis in an enlarged form by stressing Murena's merits and questioning Sulpicius's aptitude, and by underlining the faults and failures made by him during the election campaign. ${ }^{130}$ The attack against Cato, cast in humorous form, takes the edge of the charges, by which he presents the objections brought up against Murena as the outcome of the philosopher-statesman's too anxious conscience and approach alien to life. ${ }^{131}$ Emphasis of the imminence by Catilina-which Suplicius, otherwise having excellent traits and values deserving acknowledgement by all means from a human viewpoint, would not be able to efficiently oppose-reinforces Murena's position. So, Cicero as a consul defends his elected successor in office - as the verdict of acquittal shows - successfully, and the defence rests on three pillars: Murena's aptitude, Sulpicius's ineligibility and failures, and realistic recognition of the dangers of the situation in current politics.

In Plancius's lawsuit the prosecution also started a co-ordinated attack against the counsel for the defence and former consul, Cicero because the accusers believed that they could achieve their goal against Plancius only by weakening Cicero. Accordingly, Cicero highlights Plancius's merits and services by which he supported him during his exile, in the prooemium already, and builds the entire third part of the speech: the refutation of the charges made by Cas$\operatorname{sius}^{132}$ and Laterensis ${ }^{133}$ and the peroratio ${ }^{134}$ on them. Thus, the significance of the identity of the defending counsel far surpasses that of his defendant in this case too, and it can be stated that Plancius's acquittal was owing almost exclusively to Cicero's moral weight, independently of the acts and failures of the accused. From among contentio dignitatis and exploration of the causes of Late-

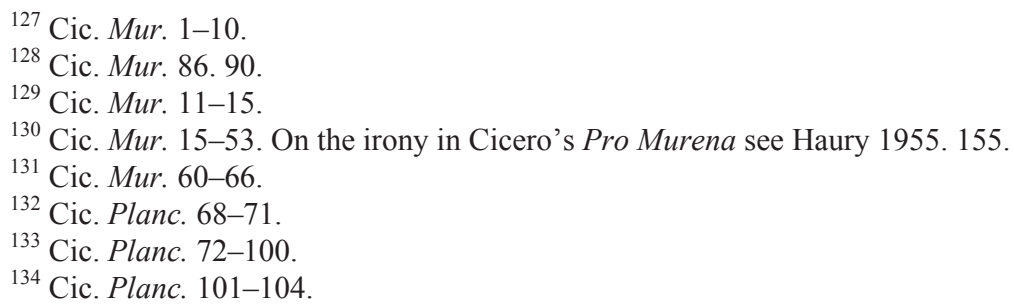


rensis's election defeat, first, the second element appears, ${ }^{135}$ on the one hand, to take care of Laterensis's sensitivity, and, on the other hand, to reduce his accuser's drive by enumerating the faults committed. Only after that comes Cicero to clearing his defendant's conduct of life, ${ }^{136}$ as it were forcing the accuser into defence position, because he - according to Cicero's argument—attacked Plancius by distorting the provisions of lex Licinia de sodaliciis, that is, in unfair manner. ${ }^{137}$ This tactics highly reminds one of the criticism against Cato-Cicero strives to convince the judges that the prosecutors' action, although it might seem to be lawful, is by all means seriously unfair. Laterensis's accuser's position could have been by no means strengthened by the somewhat condescending, patronising encouragement by which Cicero urged him not to give up hope: successes in public life will certainly not keep him waiting in the future if he learns a lesson from his faults and takes the advice he has just received. ${ }^{138}$ After having properly prepared the field, the orator refutes the actual charge of ambitus by lapidary conciseness, all the more because - as Cicero argues henceforth in the contentio dignitatis-Plancius's favourable opportunities and aptitude, and the support provided by him, among others, to him as exiled former con$s u l,{ }^{139}$ made it unjustified from the first for his defendant to use unlawful tools. ${ }^{140}$

From the Ciceronian practice of ambitus lawsuits it can be unambiguously ascertained that the judgment and, as its antecedents, the role of the prosecution and the defence orientated itself primarily in terms of political aspects. The party who brought the charge was often a competitor beaten in the elections, who could not only expect the proceedings to impose sanctions on unlawful practices through the conviction of his one-time competitor, the accused in the lawsuit, but, based on Roman practice, could certainly count also on obtaining the office that he had not been able to obtain by winning the electors over, as a benefit of the lawsuit. Consequently, when deciding the issue of guilt or innocence, the judges deliberated the past, conduct of life of the accuser and the accused, i.e., the winner and loser of the elections, the necessities demanded by the situation of current politics, the eligibility of the parties concerned and-as Pro Murena and Pro Plancio convincingly proves it - the political weight of the patronus who took action for the sake of the accused. ${ }^{141}$

\footnotetext{
${ }^{135}$ Cic. Planc. $5-30$.

${ }^{136}$ Cic. Planc. $30-35$.

${ }^{137}$ Cic. Planc. 36-48.

${ }^{138}$ Cic. Planc. $49-53$.

${ }^{139}$ Cic. Planc. 68-71.

${ }^{140}$ Cic. Planc. 58-67.

${ }^{141}$ Adamietz 1986. 117.
} 
Др Тамаш Нойари, ванредни йрофесор

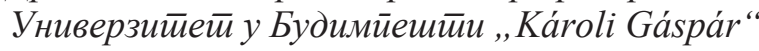

Правни факулитей

\section{Право и реторика у Цицероновом говору у одбрану Гнеја Планција}

Сажкейак: Цицеронов іовор у одбрану Гнеја Планција (Cnaеus Planсіиs) одржан је у рану јесен 54. іодине йре н. е., нейосредно йре или йосле іовора у одбрану М. Емилија Скаура. Планције је освојио функиију едила за 54. іодину йобедом на изборима, али како йо у Риму није било неуобичајено, юеїов йобеђени конкуренй М. Јувенције Лайеренс оййужио іа је за из-

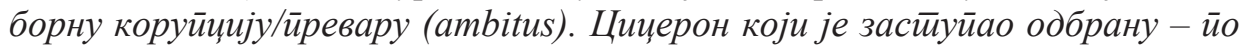
сойсиввеном обичају - иоследюи је узео реч. Цицерон је био у ирисној вези

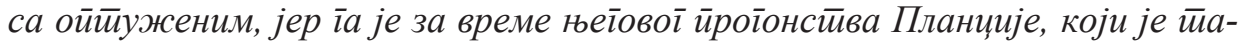
да био квестиор у Македонији, ирихвайио, ийо је іоворник смайрао йравим сйасавањем живойа. Мада је Цицерон донекле, али не баш исирйно реаїовао на йлавне стиавке ойтужже, он је својим іовором йажну слушала-

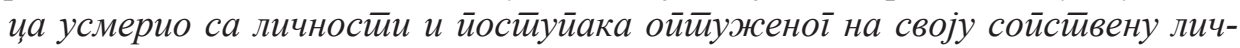

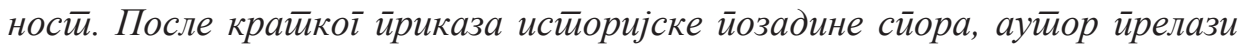
на дейаљнију анализу случаја Pro Plancio, на исииитиивање Цицероновоі начина рет̄оричко̄̄ руковања чињеницама, који, ради лакиеі разумевања, у

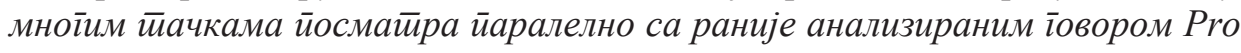
Murena.

Кључне речи: римско казнено йраво; избори; crimen ambitus; йодмићивање; Marcus Tullius Cicero. 
